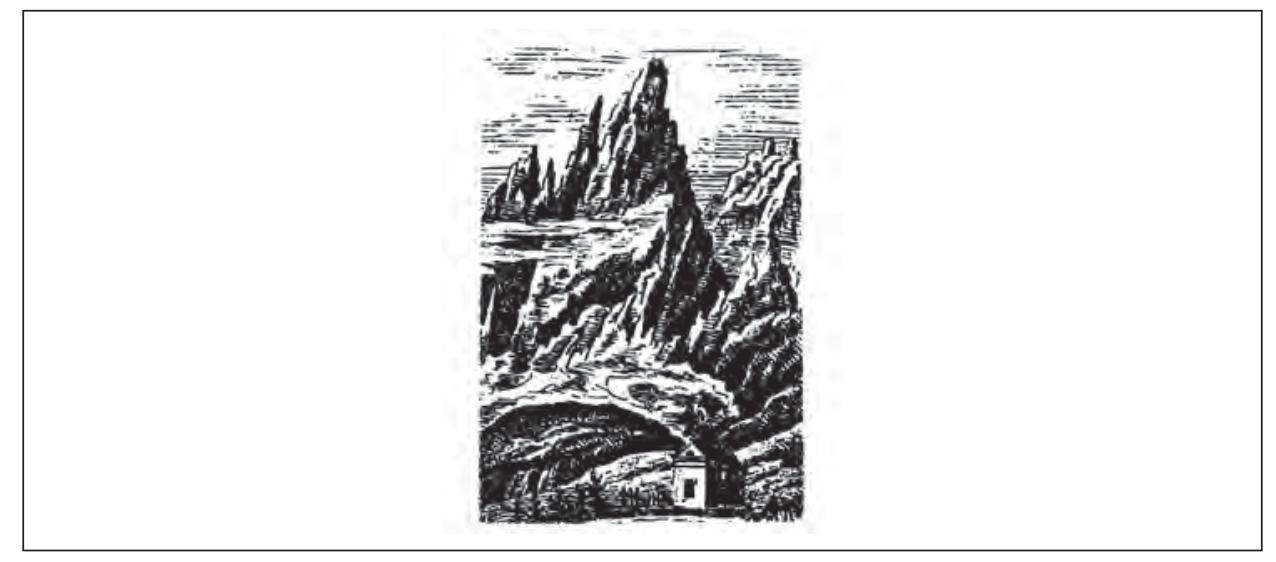

\author{
Tomasz Przerwa \\ ORCID: 0000-0001-8972-0773 \\ Uniwersytet Wrocławski \\ tomasz.przerwa@uwr.edu.pl
}

https://doi.org/10.19195/2084-4107.13.22

\title{
Odidealizowane? \\ Góry w rozwoju sportów zimowych w Sudetach przed 1945 rokiem
}

\author{
Słowa-klucze: Sudety, sporty zimowe, kultura masowa, idealizacja gór
}

Keywords: Sudetes, winter sports, mass culture, idealisation of the mountains

\section{De-idealised? Mountains in the development of winter sports in the Sudetes before 1945}

\section{Summary}

The development of tourism changed the way of seeing and developing the Sudetes, and the rapid growth in winter sports - which began at the turn of the twentieth century - should be regarded as one of the most important elements in this process. There emerged a new group of "mountain consumers" who did not focus on experiencing the mountains, but pay more attention to using them for tourism- and sports-related purposes. Profound reflection was replaced by activity, which became the main medium of new fascinations. Alongside snow the mountains were a prerequisite for the expansion of tobogganing or skiing, but did this determine their idealisation or loss of their 
charm? An answer to this question is quite complex, as it requires us to take into account broader cultural transformations, and the available sources do not provide unequivocal evidence. Nevertheless, it is possible to discern a shifting of accents, or perhaps just addition of new ones, including rise in the stature of sporting rivalry and discovery of the beauty of winter. Naturally, all these aspects concern not only the Sudetes.

Góry nie zawsze były idealizowane, nie zawsze też wzbudzały pozytywne emocje. Z czasem zaczęły jednak przyciągać poetów, pięknoduchów i wrażliwców, których przykład okazał się niezwykle istotny w fazie turystycznego oswajania przestrzeni górskich. Wyrażany przez nich zachwyt — prawdziwy, względnie wypozowany - tworzył pozytywne konteksty i konotacje, co pomogło przełamać dawniejsze lęki i kulturowe uprzedzenia. Począwszy od XVIII wieku, zamiłowanie do gór stopniowo narastało i sprzęgło się ze wzbierającą popularnością praktyk turystycznych, które gdzieś na przełomie XIX i XX wieku stały się częścią kultury masowej. Ta nie przekreślała wprawdzie idealistycznego postrzegania gór; prowadziła niemniej do ich zagospodarowania i komercjalizacji, a poprzez to pozbawiała je szczególnej aury. Sygnalizowane problemy warte byłyby wielopłaszczyznowych rozważań, których zakres daleko jednak wykracza poza ramy niniejszego wystąpienia, dlatego poprzestańmy na analizie wybranych zjawisk z przełomu XIX i XX wieku, kiedy rewolucje mentalne przekładały się na zmiany infrastrukturalne i skokowy wzrost liczby turystów odwiedzających górskie okolice.

Jeden z ważniejszych przełomów tej doby wiąże się z wypromowaniem sportów zimowych, które znacząco poszerzały zakres i skalę turystycznej aktywności w górach. Sportowe fascynacje zmieniały podejście do zimy, rozbudziły ruch turystyczny w „martwych” dotychczas miesiącach zimowych, ale sprzyjały też przesuwaniu górnej granicy zagospodarowania turystycznego. Peryferyjne dawniej osady górskie przekształcały się w tętniące życiem ośrodki sportowe, które obrastały nowoczesną infrastrukturą noclegową, transportową i sportową. W obliczu nieznanych wcześniej praktyk same góry jakby traciły jednak na znaczeniu, a odpowiednia pogoda znaczyła dla ich nowych „konsumentów” więcej niż gloryfikowane onegdaj szczyty. Owa generalizacja wymaga, naturalnie, ostrożnego potraktowania, ale, uwzględniając niejednorodność występujących w tym zakresie motywów i wyobrażeń, warto mimo wszystko zapytać, czy wizja idealnych warunków śniegowych nie zaszkodziła aby idealizacji górskich przestrzeni; czy zimowe góry podlegały w ogóle idealizacji, czy też stały się mimowolnym świadkiem nowych fascynacji, placem zabaw lub areną sportową.

Udzielenie odpowiedzi na te oraz kolejne pytania niesie oczywiste trudności i zastrzeżenia; możemy wszak oprzeć się na zachowanych źródłach, przede wszystkim na relacjach prasowych i wspomnieniach, a te z pewnością nie oddają pełnego obrazu postrzegania obszarów górskich przez miłośników narciarstwa, saneczkarstwa i innych form zimowej rekreacji. Lektura licznych wypowiedzi pozwala przecież uchwycić pewną prawidłowość czy też tendencję, której nie sposób wprawdzie uogólnić, ale wypada przynajmniej uwzględnić. Takie podejście do 


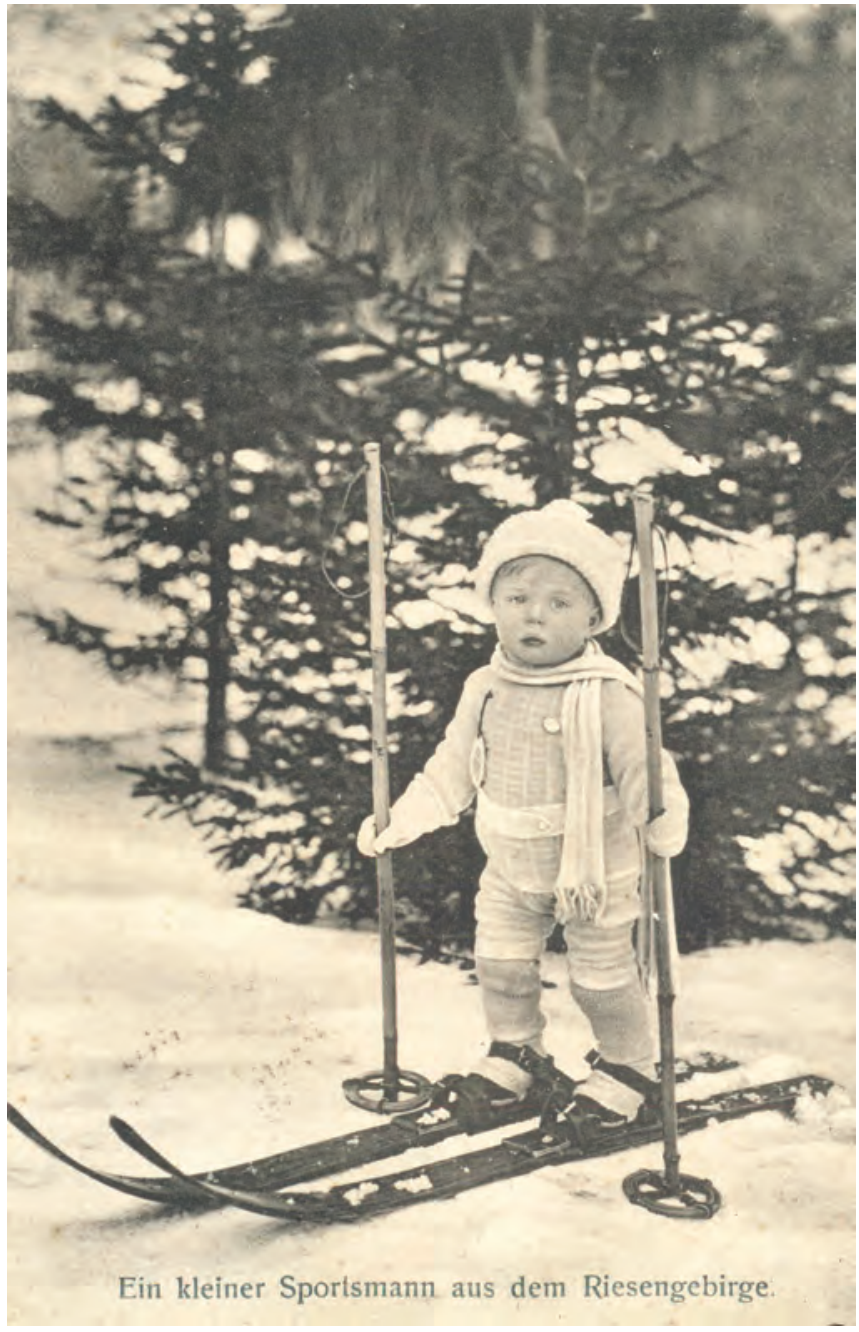

1. Pocztówka karkonoska (początek XX wieku), zbiory prywatne Tomasza Przerwy

problemu zwalnia nas z obowiązku rozpatrywania każdego szczegółu i każdego zakątka, dlatego poprzestaniemy na przedstawieniu jednej tylko krainy górskiej - Sudetów ${ }^{1}$. Trudno je wprawdzie zaliczyć do regionów kształtujących modę na sporty zimowe, ale we wskazanym zakresie badań nie jest to raczej zarzutem, ponieważ niejaka przeciętność oddaje właściwe oblicze zjawiska. Nie sposób przy tym przemilczeć, że wspomniane Sudety — a właściwie Karkonosze — należały

1 Obszernie na ten temat zob. T. Przerwa, Między lękiem i zachwytem. Sporty zimowe w ślaskich Sudetach i ich znaczenie dla regionu (do 1945 roku), Wrocław 2012. 
w przeszłości do najwcześniej rozwiniętych turystycznie masywów górskich Europy, czego dowodzi nowożytna popularność wypraw na Śnieżkę².

Wypada dopowiedzieć, że również zimowe wyprawy w Karkonosze zostały zapoczątkowane z pewnym wyprzedzeniem, co nie przełożyło się jednak na ich ponadlokalne wypromowanie. Chodzi o rekreacyjne zjazdy saniami rogatymi, które w rejonie Kowar znane były przynajmniej od 1817 roku, kiedy zachwycił się nimi pruski generał August Neithardt von Gneisenau, właściciel majątku w pobliskich Mysłakowicach. Nową podówczas rozrywkę należałoby uznać przy tym za lokalną anomalię turystyczną, z której dopiero końcem XIX wieku rozwinął się właściwy produkt turystyczny. Chętnych wywożono na Przełęcz Kowarską saniami, na których później — po wyprzężeniu koni — także zjeżdżano. W obie strony prowadził je miejscowy „góral”, a turyście pozostawało biernie kontemplować krajobraz. Zjazdom towarzyszyła ekscytacja zawrotnymi jak na ten czas prędkościami. Z zachowanych opisów wynika, że atrakcyjność przejażdżek saniami rogatymi zasadzała się właśnie na ich wyjątkowości, przekraczaniu tradycyjnych barier i posmaku ryzyka. Nieodzownym elementem wypraw była nadto biesiada w górskim schronisku, gdzie liczyło się obfite nakrycie stołu i wesołe towarzystwo. Wymienione „atrakcje” nie wykluczają, oczywiście, i innych doznań bądź oczekiwań3.

Nie mamy podstaw, by przypuszczać, że zjazdy saniami rogatymi na przełomie XIX i XX wieku nabrały innego wymiaru. W podstawowym opracowaniu Bertholda Lessenthina z 1901 roku poświęconym karkonoskiej zimie (Das Riesengebirge im Winter) znajdziemy wprawdzie potwierdzenie kariery sań rogatych (między innymi wśród berlińczyków), ale jej źródłem z pewnością nie była (sama) afirmacja gór. Podobnie rzecz miała się z promowanymi podówczas zjazdami saneczkami, które powielały w Karkonoszach i innych masywach górskich Śląska znane nam już sprzężenie zachwytu wobec zimowej przyrody, towarzyskiej zabawy z dreszczykiem emocji. Ważną innowacją było przejęcie pełnej kontroli nad zjazdem przez turystów. W przeróżnych wydawnictwach promujących zimową aktywność ruchową kładziono nacisk właśnie na potrzebę przełamania zimowej pasywności i na zdrowotny wymiar rekreacji zimowej, która nie wymagała wcale wypraw w wysokie góry. Niektóre tory saneczkowe reklamowały się zatem łagodnością profilu i ogólnym bezpieczeństwem. Szukano zresztą dodatkowych atrakcji. W trakcie zjazdów saneczkowych przygrywały kapele, a nocnym imprezom

2 Szerzej zob. m.in. J. Kolbuszewski, Z dziejów Śnieżki w Karkonoszach, Warszawa-Kraków 1990; R. Kincel, Sarmaci na Śnieżce, Wrocław 1973; H. Gruhn, Die Erschließung des Riesengebirges bis zum Jahre 1700, „Zeitschrift des Vereins für Geschichte Schlesiens” 62, 1928, s. 116-146; idem, Reisen zur Schneekoppe im frühen 18. Jahrhundert. Ein Beitrag zur Erschließung des Riesengebirges, „Zeitschrift des Vereins für Geschichte Schlesiens” 65, 1931, s. 391-411.

3 Zob. B. Lessenthin, Das Riesengebirge im Winter, Wrocław 1901, s. 58-62; M. Neumann, Hörnerschlittenfahrten im Riesengebirge, „Bergwacht” 1.01.1953, s. 4-5; E. Ratajczak, Kowarskie sanie rogate - śnieżny wehikuł czasu, Kowary 2006. 
towarzyszył blask pochodni. Góry tworzyły niezwykłą scenerię dla wspominanych praktyk, ale można przyjąć, że to owe praktyki stały w centrum zainteresowania 4 .

Pionierzy narciarstwa i turyści przemierzający zaśnieżone Sudety nie pozostawili zbyt wielu relacji, co oddaje poniekąd marginalne znaczenie tych form aktywności przed nastaniem XX wieku. Wywodzili się oni często ze zrzeszeń górskich i poszukiwali możliwości podtrzymania kontaktu z ukochanymi górami w miesiącach zimowych, co pozwala domniemywać, że przynajmniej w tym kręgu mógł dominować zachwyt samymi górami. Dość szybko dostrzeżono przy tym, że zaśnieżone szczyty są inne. Doszło do syntezy piękna gór i odkrywanego właśnie uroku zimy, co tworzyło niejako nową perspektywę. Zimowy krajobraz górski stawał się punktem odniesienia, a poniekąd osobnym bytem. Jego specyfikę starali się uchwycić malarze, fotografowie, a w okresie międzywojennym - również operatorzy filmowi, których inspirowały głośne filmy górskie Arnolda Fancka. Z zimowych pejzaży Karkonoszy słynął Friedrich Iwan, w którego pracach ośnieżone góry zachwycają majestatem, wabią tajemnicą, ciszą i spokojem ${ }^{5}$. O ile zawierzyć słowom Heinricha Tüpkego, jednego z pierwszych malarzy zafascynowanych zimowymi plenerami karkonoskimi, pociągała ich kolorystyka. O swoim zetknięciu z Karkonoszami pisał po latach: „Oczarowała nas wielka płaszczyzna białych łąk i srebrny grzbiet”; dopowiadał zarazem: „Ich malowanie wymagało wielkiej ofiary czasu i zdrowia, stąd przynajmniej ja tego zaniechałem"6. Trudno dziwić się jego zniechęceniu, gdy weźmie się pod uwagę spartańskie warunki oferowane gościom w nieogrzewanych schroniskach na przełomie XIX i XX wieku.

Zimowe pobyty w Karkonoszach/Sudetach stawały się jednak coraz przyjemniejsze, a narciarstwo jeszcze przed pierwszą wojną światową wyrosło na najbardziej popularną formę rekreacji zimowej. Okres międzywojenny przyniósł jego umasowienie, a zarazem usportowienie. W latach dwudziestych XX wieku olbrzymie zainteresowanie budziły skoki narciarskie; w latach trzydziestych XX wieku zachłyśnięto się narciarstwem alpejskim. W rozbudowywanych pośpiesznie ośrodkach sportów zimowych stawiano coraz to większe skocznie narciarskie, wytyczano profesjonalne trasy biegowe i zjazdowe. W Karpaczu, Szklarskiej Porębie, Świeradowie-Zdroju i Dusznikach-Zdroju powstawały sportowe tory bobslejowe i/lub saneczkowe; szykowano także lodowiska ${ }^{7}$. Oddawano do użytku kolejne schroniska górskie (narciarskie) i jedynie w zakresie inwestycji komunikacyjnych nie odnotowano spektakularnych sukcesów. Z zazdrością spoglądano zatem na alpejskie (i nie tylko) koleje linowe oraz wyciągi narciarskie, które stawały się

4 T. Przerwa, op. cit., s. 218-222.

5 H. Pichler, Friedrich Iwan (1889-1967) und das Riesengebirge, Marktoberdorf 1997; K. Kułakowska, E. Ratajczak, Twórczość Friedricha Iwana (1889-1967), Jelenia Góra 2002.

${ }^{6}$ Cyt. za: K. Bartnik, Malarze wrocławscy i Karkonosze, [w:] Wspaniaty krajobraz: Artyści $i$ kolonie artystyczne w Karkonoszach w XX wieku, red. K. Bździach, Berlin-Jelenia Góra 1999, s. $176-177$.

7 J. Potocki, Rozwój zagospodarowania turystycznego Sudetów od połowy XIX wieku do II wojny światowej, Jelenia Góra 2004; T. Przerwa, op. cit., s. 200-216, 233-238, 244-249, 267-275, $335-350$. 
oczekiwanym dopełnieniem infrastruktury turystycznej ${ }^{8}$. Wytrawni narciarze ze Śląska twierdzili wprawdzie, że nie są im one potrzebne, a radość towarzysząca zjazdom nagradza wysiłek włożony w podejście na grzbiet górski ${ }^{9}$, ale na pewno nie była to postawa powszechna. Zauważmy przy tej okazji, że głównym motywem aktywności sportowców stał się ruch, zmaganie z przeszkodami i własnymi słabościami, a przestrzeń schodziła jakby na dalszy plan.

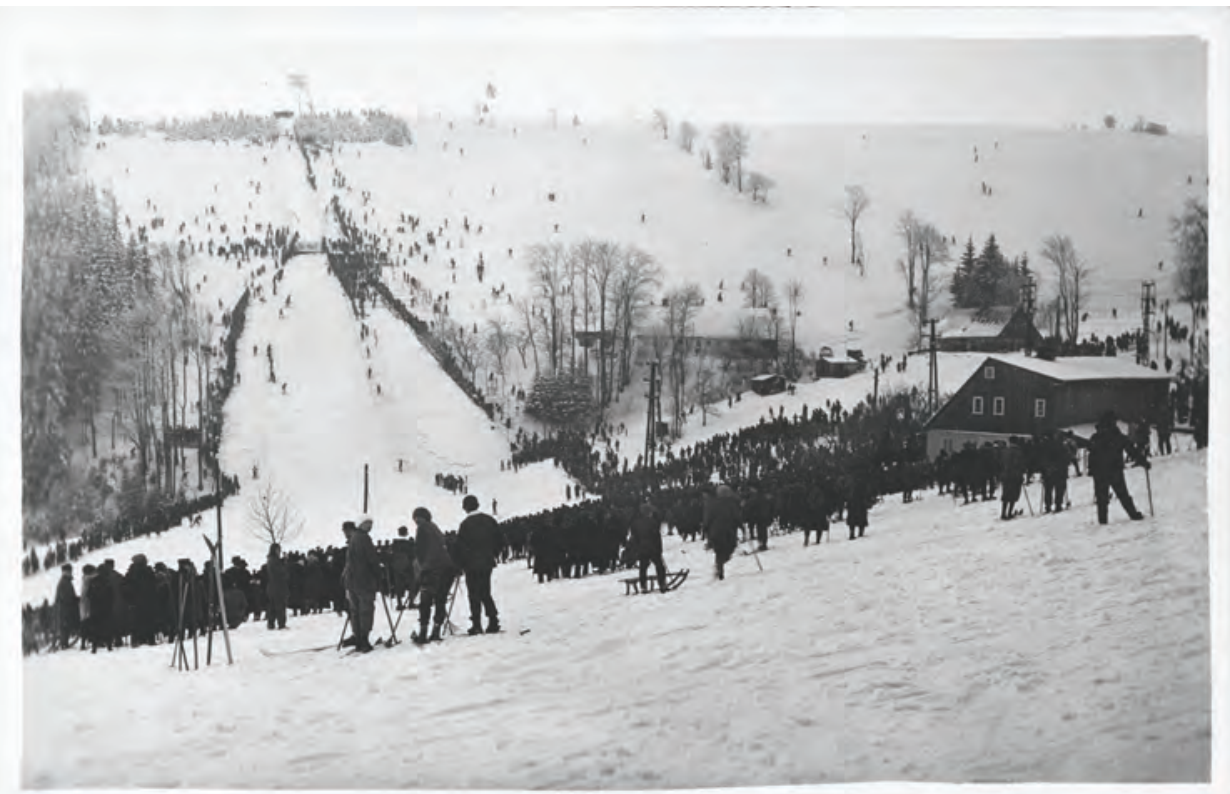

2. Zawody w skokach narciarskich w Sokolcu (przełom lat dwudziestych i trzydziestych $\mathrm{XX}$ wieku), zbiory prywatne Tomasza Przerwy

W modnych kurortach zimowych pojawiało się zresztą sporo gości skupionych na relacjach towarzyskich. Jeden z komentatorów nazwał Karpacz lat dwudziestych XX wieku ,jaskinią grzechu”. Inny pisał w podobnym czasie, że wspomniany kurort różni się od berlińskiej metropolii jedynie tym, że na spotkania towarzyskie przychodzi się tam w strojach sportowych. Na ulicach zaś miały królować: zapach benzyny, pudru i perfum. Wszędzie widywano wytwornie ubranych gości. Ten typ klientów miał przeważać w centrum i na niżej położonych terenach narciarskich, przy czym narty i sanki były rzekomo jedynie pretekstem do flirtów. Prawdziwa brać narciarska miała przodować dopiero na grzbiecie górskim. Umasowienie narciarstwa niewątpliwie utrudniało zachowanie szczególnego ducha z pionierskiego okresu jego rozwoju. Pisał o tym jeden z wetera-

8 T. Przerwa, Koleje turystyczne i wyciagi sportowe w Sudetach do 1945 roku - próba bilansu, [w:] ,, Mkna po szynach...” Z dziejów transportu i komunikacji na ziemiach polskich na przestrzeni wieków, red. T. Głowiński, R. Klementowski, Wrocław 2014, s. 241-250.

9 M. Neumann, Ein Ski-Sonntag im Riesengebirge, „Schlesische Bergwacht” 19.04.1955, s. 11. 
nów i w ironicznym tekście wyśmiewał nowe trendy. Wspominał o zrzeszeniach narciarskich, których członkowie zbierają się po schroniskach i organizują tam huczne imprezy, o klubach skupionych na samym pomnażaniu liczby członków, o wygodnych dojazdach do eleganckich schronisk-hoteli czy też o narciarzach owładniętych myślą zdobycia sportowych laurów ${ }^{10}$.

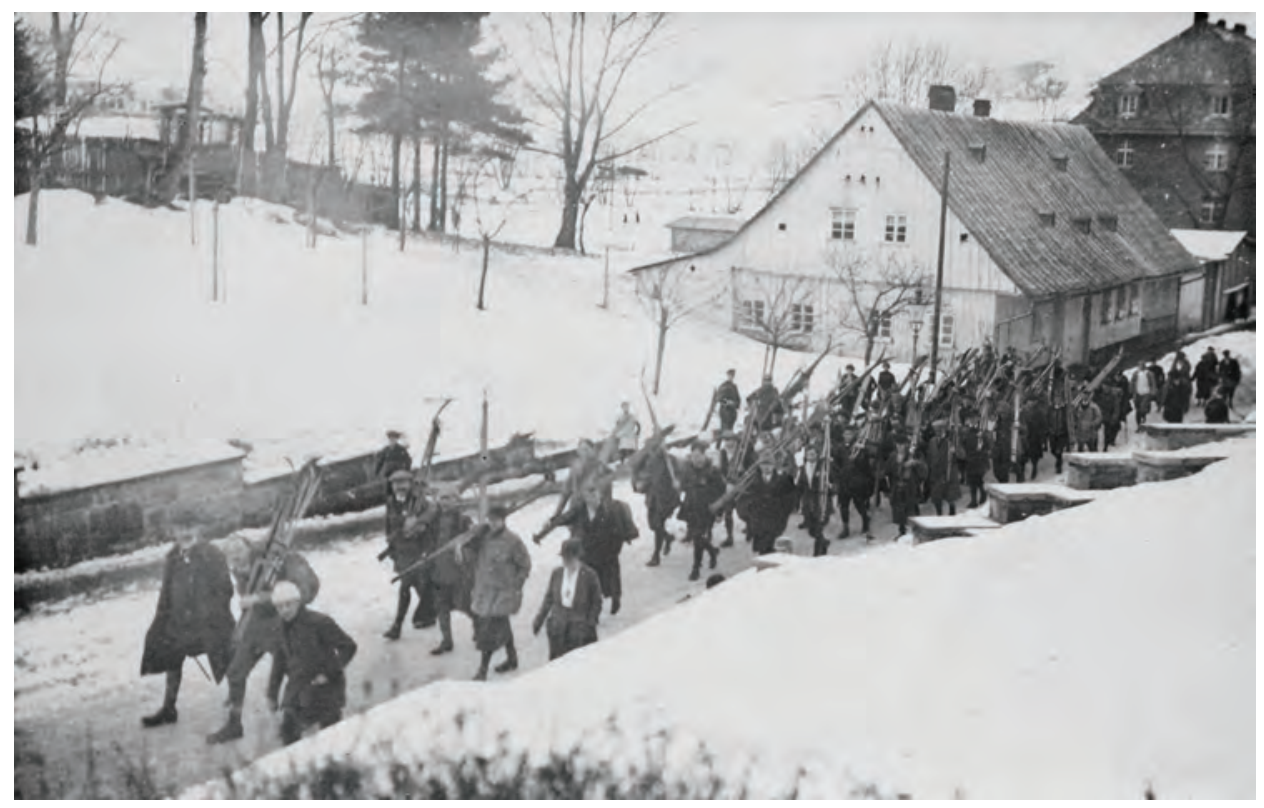

3. Grupa narciarzy przybyłych do Dusznik-Zdroju (okres międzywojenny), zbiory prywatne Tomasza Przerwy

Narty zapewniały mieszkańcom gór mobilność i nowe źródła zarobkowania; przybysze poszukiwali w narciarstwie odskoczni od codzienności. Wyruszali na szlaki, aby zakosztować uroków zimy, sprawdzić się lub aktywnie wypocząć. Wszyscy liczyli na odpowiednie warunki śniegowe. Nic dziwnego, że podczas ciepłych lub kapryśnych zim okresu międzywojennego proszono „boga pogody" (Wettergott) o puszysty śnieg i lekki mróz oraz słoneczną i stabilną pogodę. Spełnienie wszystkich tych oczekiwań nie było wcale częste, dlatego poświęcano im wiele miejsca. Wahania pogody budziły niecierpliwość, a nawet tęsknotę za czasami, kiedy zimy były jakoby sroższe. Narzekanie na aurę w okresie międzywojennym brało się zatem bardziej z zawodu, że śnieżne zimy — pamiętane jako dopust boży — zawodziły w okresie, kiedy były niecierpliwie wyczekiwane przez

10 H. Reitzig, So war es damals..., „Heemteglöckla” 1954, nr 40, s. 1-6; A. Kosch, Warum ins Isergebirge zum Skilaufen?, „Schlesischer Wintersport” 25.03.1933, s. 205-206; Ch. Plehan, Mit dem Sonderzuge ins Isergebirge, „Schlesischer Wintersport” 7.01.1927, s. 1-2; W. Mohr, Mit Skiern in Rübezahls Reich, „Schlesischer Wintersport” 25.03.1927, s. 1-2; Igitus, Zeitgemäß!, „Schlesischer Wintersport" 19.01.1928, s. 1-2. 
mieszkańców górskich miejscowości i ich gości. Niekiedy, aby odgonić nudę, posiłkowano się humorem. W Dusznikach-Zdroju w 1932 roku odbyła się „demonstracja”, podczas której grupa przebierańców „,domagała się” od miejscowych władz śniegu! ${ }^{11}$

Najlepsze warunki śniegowe znajdowano zwykle w wyższych partiach gór, które obrastały infrastrukturą turystyczną i sportową. Najdalej w tym względzie przekształcono górę Przedział koło Szklarskiej Poręby, którą w 1925 roku „wzbogacił" nowoczesny, wzorcowy tor bobslejowy Zackelfallbobbahn, powiązany z wyciągiem elektrycznym, a po kilku latach wystawiono w pobliżu dużą skocznię narciarską Himmelsgrundschanze ${ }^{12}$. W materiałach prasowych wiele pisano o ich walorach technicznych, rozgrywanych na nich zawodach (w tym rangi międzynarodowej) i bitych tam rekordach; problemom ekologicznym nie poświęcano (większej) uwagi. Lokalnym elitom zależało wszak na wzmocnieniu sportowej marki wiodących ośrodków sportowych, a co za tym idzie — branży turystycznej. Starały się one wyjść naprzeciw miłośnikom narciarstwa, saneczkarstwa i bobslejów, którzy szukali odpowiednich warunków do uprawiania preferowanych przez siebie sportów. Zwolennicy naturalnych krajobrazów zawsze mogli wybrać się w okolice słabiej zagospodarowane i wypromowane, w tym w sąsiednie Góry Izerskie.

Szeroko nagłośniony w mediach — prasie i radiu — sport wyczynowy nie zaspokajał wszystkich potrzeb miłośników zimowych Sudetów. Spora grupa sympatyków sportów zimowych poprzestawała na wędrówkach narciarskich, bliższych aktywności turystycznej niźli sportowej. Nie były one specjalnie promowane, dlatego zostały przysłonięte i skazane na niepamięć. Można zatem jedynie spekulować, czy właśnie w obrębie tej grupy nie doświadczano aby mocniej wzniosłości gór, wobec której człowiek pozostawał w zachwycie i pokorze ${ }^{13}$. Pozostaje przy tym ogólna niepewność, czy to duch sportowej rywalizacji odestetyzowywał przestrzeń górską, czy też zasadniczo chodziło o pośpiech i powierzchowność masowego odbiorcy. Ten drugi wariant dobrze współgra $\mathrm{z}$ negatywną oceną turystyki karkonoskiej z początków XX wieku, wyrażoną przez Mieczysława Orłowicza, krytykującego komercjalizację gór i konsumpcjonizm nawiedzających je tłumów ${ }^{14}$. W słowach nestora polskiej turystyki pobrzmiewa wyraźna niechęć do filisterskich zachowań Niemców, ale też nuta dydaktyzmu, ostrzeżenia przed spowszednieniem gór. Rozkwit sportów zimowych w Sudetach wpisywał się w scenariusz ich uzwyczajnienia, a nawet wykraczał poza jego ramy, ponieważ skupiał uwagę na nowych wątkach — przeżyciach sportowych.

11 Trotz des neuerlichen Witterungsumschlags, „Echo des Heuscheuer- und Mense-Gebirges. Reinerzer Stadt-Blatt" 6.01.1932, s. 2.

${ }^{12}$ P. Wiater, Zimowe zagospodarowanie sportowo-turystyczne terenów wokót Wodospadu Kamieńczyk do 1945 r., „Śląski Kwartalnik Historyczny Sobótka” 58, 2003, s. 415-422.

13 T. Przerwa, Między lękiem..., s. 106-127.

14 M. Orłowicz, Moje wspomnienia turystyczne, Wrocław-Warszawa-Kraków 1970, s. 231, $519-521$. 
Analiza zawartości ogólnośląskiego periodyku sportowego „Schlesischer Wintersport" i lokalnej prasy, w tym kilkudziesięciu roczników dusznickiej gazety „Echo des Heuscheuer- und Mense-Gebirges”, nie wskazuje na przesadne zainteresowanie górami autorów piszących na temat sportów zimowych ${ }^{15}$. Piękne czy też idealne wydawały się im obiekty sportowe i warunki pogodowe, w szerszym ujęciu — zima lub zimowa przyroda. O ,idealnych” górach wspominano w prasowych wypowiedziach sporadycznie i to w kontekście „idealnych” warunków do uprawiania narciarstwa (między innymi das ideale Skigelände, Skiparadies). Nieliczne odstępstwa od wspomnianej normy, nawiązania do uroku gór bądź piękna okolicy ${ }^{16}$, są przy tym nie tylko ogólnikowe, ale też wydają się pozbawione większego znaczenia i głębszej treści. Pobrzmiewa w nich akceptacja wdzięku gór, ale on sam nie był przecież w danym momencie najważniejszy. W centrum uwagi znajdowały się wątki praktyczne, techniczne i bieżące. Takie podejście znajdziemy również $\mathrm{w}$ sudeckich informatorach, poradnikach i przewodnikach narciarskich ${ }^{17}$. Wspomnienia publikowane w powojennych periodykach ziomkowskich podobnie koncentrowały się na osiągnięciach sportowych, działaniach organizacyjnych i jednostkowych zdarzeniach ${ }^{18}$. Nie tworzono wielkich narracji, nie kreowano nowych pojęć czy wzorów; oddawano się przedstawianiu codzienności.

W śląskich periodykach turystycznych, sportowych i regionalnych względnie często w sezonie zimowym drukowano wiersze i krótkie opowiadania poświęcone postrzeganiu i doświadczaniu zimy. Literacka formuła tych wypowiedzi nie oznaczała jednak szczególnego przewartościowania treściowego, a ośnieżone góry pozostawały jedynie składową większego zestawu tematycznego. Poziom artystyczny tych utworów jest zresztą — oględnie rzecz ujmując — dość przeciętny. Wyrażały one emocje i ambicje piszących, co czyni z nich atrakcyjny obiekt naukowych analiz literaturoznawców i kulturoznawców; szerszego uznania jednak nie zdobyły. Wzrastająca popularność sportów zimowych nie znajdowała raczej należytego odzwierciedlenia w kulturze przedwojennego Śląska. Zakorzeniały się w obrębie zachowań społecznych, ale więcej znaczyły w sferze gospodarczej niźli w tradycyjnym wymiarze kulturowym. Można było przeczytać o nich w prasie i specjalistycznych wydawnictwach, ale poza ten zawężony zakres wychodziły

15 „Schlesischer Wintersport” 1924-1936; „Echo des Heuscheuer- und Mense-Gebirges. Reinerzer Stadt-Blatt” 1905-1934; „N-S Echo. Nationalsozial. Kampfblatt der Grafschaft Glatz und des Großkreises Frankenstein-Münsterberg" 1934-1940.

16 Zob. F. Weiß, Skiwettlauf, ,Rund um die Heuscheuer “, „Schlesischer Wintersport” 29.01.1926, s. 1; J.B., Winter im Adlergebirge, „Schlesischer Wintersport” 29.01.1926.

17 Zob. np. W. Dressler, Winter in Schlesiens Bergen: Riesen- u. Isergebirge, Waldenburger Bergland, Eulengebirge, Grafschaft Glatz, Altvatergebirge, Wrocław 1939; M. Baganz, Das Skiwanderbuch des Riesengebirges, Berlin 1925; W. Reimann, Schifahren durch das Eulengebirge und die Waldenburger Berge, Waldenburg 1922; P. Werth, Wintersport im Riesengebirge, Berlin 1914.

18 „Grafschafter Bote” 1950-2004; „Hohe Eule” 1952-2004; „Riesengebirgsbote” 19491988; „Schlesische Bergwacht” 1950-2004; K.Ch. Kasper, Winterfreuden und Winterleid, BonnOberkassel 1997. 
nieczęsto $^{19}$. W zestawie zimowych tematów centralne miejsce nadal zajmowało Boże Narodzenie i Nowy Rok ${ }^{20}$.

Pozostaje stwierdzić, że fascynacja śniegiem, prędkością czy wynikami nie wykluczała idealizacji gór, obsypanych w tym przypadku białym puchem i skrzących się w słońcu. Górska sceneria nie mogła być całkiem obojętna miłośnikom sportów zimowych, skoro napomykano o niej nawet w kontekście zawodów i infrastruktury sportowej. Magia gór nie zajmowała może pierwszorzędnego miejsca w wypowiedziach miłośników „białego szaleństwa”, ale zapewne nadal oddziaływała. Trwała, była oczywista i być może właśnie przez to jakby mniej konieczna do wyrażenia. Intymne rozumienie gór nie współgrało zresztą z natłokiem sportowych doświadczeń i towarzyszącą im konwencją. Aktywność sportowa rozkwitała jako element kultury masowej — w związku z czym wymiar czysto duchowy nie był jej szczególnie użyteczny. Pozostajemy poniekąd w stanie niepewności, czy w ogóle potrafimy właściwie odczytać postrzeganie gór w nowej, ważnej grupie ich odbiorców, która postanowiła odwiedzić je zimą. Wypada przecież dostrzec przesunięcie akcentu z przestrzeni górskiej na czynność, z nastawienia refleksyjnego na kwestie praktyczne i bieżące, z podziwu dla zastanego świata na potrzebę jego dopasowania do nowych potrzeb.

\section{Bibliografia}

Baganz M., Das Skiwanderbuch des Riesengebirges, Berlin 1925.

Bartnik K., Malarze wroctawscy i Karkonosze, [w:] Wspaniały krajobraz: Artyści i kolonie artystyczne w Karkonoszach w XX wieku, red. K. Bździach, Berlin-Jelenia Góra 1999.

Dressler W., Winter in Schlesiens Bergen: Riesen- u. Isergebirge, Waldenburger Bergland, Eulengebirge, Grafschaft Glatz, Altvatergebirge, Wrocław 1939.

Gruhn H., Die Erschließung des Riesengebirges bis zum Jahre 1700, „Zeitschrift des Vereins für Geschichte Schlesiens" 62, 1928.

Gruhn H., Reisen zur Schneekoppe im frühen 18. Jahrhundert. Ein Beitrag zur Erschließung des Riesengebirges, „Zeitschrift des Vereins für Geschichte Schlesiens” 65, 1931.

Igitus, Zeitgemäß!, „Schlesischer Wintersport” 19.01.1928.

J.B., Winter im Adlergebirge, „Schlesischer Wintersport” 29.01.1926.

Kasper K.Ch., Winterfreuden und Winterleid, Bonn-Oberkassel 1997.

Kincel R., Sarmaci na Śnieżce, Wrocław 1973.

Kolbuszewski J., Z dziejów Śnieżki w Karkonoszach, Warszawa-Kraków 1990.

Kosch A., Warum ins Isergebirge zum Skilaufen?, „Schlesischer Wintersport” 25.03.1933.

Kułakowska K., Ratajczak E., Twórczość Friedricha Iwana (1889-1967), Jelenia Góra 2002.

Lessenthin B., Das Riesengebirge im Winter, Wrocław 1901.

Mohr W., Mit Skiern in Rübezahls Reich, „Schlesischer Wintersport” 25.03.1927.

Neumann M., Hörnerschlittenfahrten im Riesengebirge, „Bergwacht” 1.01.1953.

Neumann M., Ein Ski-Sonntag im Riesengebirge, „Schlesische Bergwacht” 19.04.1955.

19 Interesującym wyjątkiem wydaje się znana powieść Paula Kellera pod tytułem „Waldwinter" z 1902 roku, w której fabułę autor wplótł opis zimowej wyprawy w Karkonosze.

20 T. Przerwa, Zima w kulturze ziemi kłodzkiej, [w:] Kultura ziemi kłodzkiej-tradycje i wspótczesność, red. E. Białek, W. Browarny, M. Ruchniewicz, Wrocław 2016, s. 514-525. 
Orłowicz M., Moje wspomnienia turystyczne, Wrocław-Warszawa-Kraków 1970.

Pichler H., Friedrich Iwan (1889-1967) und das Riesengebirge, Marktoberdorf 1997.

Plehan Ch., Mit dem Sonderzuge ins Isergebirge, „Schlesischer Wintersport” 7.01.1927.

Potocki J., Rozwój zagospodarowania turystycznego Sudetów od połowy XIX wieku do II wojny światowej, Jelenia Góra 2004.

Przerwa T., Koleje turystyczne i wyciagi sportowe w Sudetach do 1945 roku — próba bilansu, [w:] „,Mkna po szynach...” Z dziejów transportu i komunikacji na ziemiach polskich na przestrzeni wieków, red. T. Głowiński, R. Klementowski, Wrocław 2014.

Przerwa T., Między lękiem i zachwytem. Sporty zimowe w ślaskich Sudetach i ich znaczenie dla regionu (do 1945 roku), Wrocław 2012.

Przerwa T., Zima w kulturze ziemi kłodzkiej, [w:] Kultura ziemi kłodzkiej — tradycje i współczesność, red. E. Białek, W. Browarny, M. Ruchniewicz, Wrocław 2016.

Ratajczak E., Kowarskie sanie rogate - śnieżny wehikut czasu, Kowary 2006.

Reimann W., Schifahren durch das Eulengebirge und die Waldenburger Berge, Waldenburg 1922.

Reitzig H., So war es damals..., „Heemteglöckla” 1954, nr 40.

Trotz des neuerlichen Witterungsumschlags, „Echo des Heuscheuer- und Mense-Gebirges. Reinerzer Stadt-Blatt" 6.01.1932.

Weiß F., Skiwettlauf ,,Rund um die Heuscheuer“, „Schlesischer Wintersport” 29.01.1926.

Werth P., Wintersport im Riesengebirge, Berlin 1914.

Wiater P., Zimowe zagospodarowanie sportowo-turystyczne terenów wokół Wodospadu Kamieńczyk do 1945 r., „Śląski Kwartalnik Historyczny Sobótka” 58, 2003. 